\title{
Desain Robot Pelindung Tenaga Medis untuk Pasien Isolasi Novel Coronavirus (2019- nCoV) di Rumah Sakit dengan Metode Antropometri
}

\author{
Anton Siswo R.A. ${ }^{1}$, Randy Erfa S. ${ }^{2}$ \\ 1,2 Fakultas Teknik Elektro, Universitas Telkom \\ Jl. Telekomunikasi Terusan Buah Batu Indonesia 40257, Bandung, Indonesia \\ (022) 7566456 \\ raharjo@telkomuniversity.ac.id ${ }^{1}$, resaputra@telkomuniversity.ac.id ${ }^{2}$
}

Diterima : 9 Juni 2020. Disetujui: 10 Juni 2020. Dipublikasikan: 24 Juni 2020

\begin{abstract}
The need to protect medical personnel from infection of isolated patients 2019-nCoV is the highest priority. Various needs of medical personnel in very rare conditions. As a result, so many medical personnel died. Medical personnel on duty must use PPE for up to 8 hours. To overcome this problem, we designed the robot to protect the medical staff as a whole, but not to burden the medical staff. The robot is designed using the Anthropometry method and literature studies on the materials used. From the design obtained by a tubular protective robot with dimensions of $75 \mathrm{~cm}$ outside and $70 \mathrm{~cm}$ inside, available oxygen cylinders, chairs, three latex rubber gloves, empty weight less than 50kg, and can carry loads of more than 100kg. This robot can be used continuously for 4 hours with a capacity of $80 \mathrm{Ah}$ battery and a stepper machine to drive a robot of at least $11.303 \mathrm{Nm}$.
\end{abstract}

\section{Keywords: Anthropometry; Protective Robot; 2019-nCoV patient; Robot Design}

Abstrak-- Kebutuhan untuk melindungi tenaga medis dari infeksi pasien isolasi 2019-nCoV adalah prioritas tertinggi. Berbagai kebutuhan tenaga medis dalam kondisi sangat langka. Akibatnya, banyak tenaga medis meninggal. Tenaga medis yang bertugas harus menggunakan APD hingga 8 jam. Untuk mengatasi masalah ini, kami mendesain robot untuk melindungi tenaga medis secara keseluruhan, namun tidak membebani staf medis. Robot dirancang menggunakan metode Antropometri dan studi literatur pada bahan yang digunakan. Dari desain diperoleh robot pelindung berbentuk tabung dengan dimensi $75 \mathrm{~cm}$ di luar dan $70 \mathrm{~cm}$ didalam, tersedia tabung oksigen, kursi, tiga sarung tangan karet latex, berat kosong kurang dari $50 \mathrm{~kg}$ dan dapat mengangkut beban lebih dari 100kg. Robot dapat digunakan terus-menerus selama 4 jam dengan kapasitas baterei $80 \mathrm{Ah}$ dan mesin stepper untuk menggerakkan robot minimal sebesar 11,303 Nm.

Kata kunci: Antropometri; Robot Pelindung; Pasien 2019-nCoV; Desain Robot

\section{PENDAHULUAN}

Berdasarkan data dari situs resmi COVID-19 di Indonesia per 27 April 2020, terdapat 9.096 kasus dengan 1.151 pasien sembuh dan 765 pasien meninggal dunia. Dari Serikat Pekerja Farmasi dan Kesehatan Reformasi (FSP FARKES/R) menyatakan bahwa 32 dokter dan 12 perawat meninggal dikutip dari siaran pers, Minggu (12/4). Mengacu kepada aturan Standar Alat Pelindung Diri (APD) dalam Manajemen Penanggulangan Covid-19 [9] dan aturan Rekomendasi Standar Penggunaan APD untuk Penanganan COVID-19 di Indonesia [5], dengan menggunakan standar Tingkat Perlindungan III untuk dokter dan perawat.

Berdasarkan hasil wawancara antara Majalah TEMPO dengan Direktur Utara Rumah Sakit Penyakit Infeksi Sulianti Saroso, ruang standar isolasi COVID-19 di RSPI Sulianti Saroso merupakan ruangan nyaman berukuran $3 \mathrm{~m} \times 3 \mathrm{~m}$, kamar mandi dalam, televisi, interkom, ruangan bertekanan negatif, hingga kamera pengawas. Setiap hari ada kunjungan dokter, perawat, petugas kebersihan sampai pengantar makanan. Dengan menggunakan standar dari RSPI Sulianti Saroso, untuk satu pasien dibutuhkan 20 set APD dengan Tingkat Perlindungan III lengkap dalam 24 jam dan satu kali pakai. Satu set pakaian tersebut adalah masker bedah, Respirator N95, Pelindung Mata, Pelindung wajah, Sarung Tangan Pemeriksaan, Sarung Tangan Bedah, Gaun sekali pakai, Coverall Medis, Heavy Duty Apron, Sepatu boot anti air, dan Penutup sepatu.

Untuk mengatasi terjadinya kontak langsung antara pasien COVID-19 dengan tenaga medis, berbagai cara telah dilakukan, salah satunya adalah dengan memanfaatkan robot sebagai media pemantauan jarak jauh untuk tenaga medis terhadap pasien COVID-19 [14][16]. Penggunaan robot 
tersebut telah berhasil memberikan pembatasan kontak langsung antara pasien dengan tenaga medis. Namun, karena berhubungan dengan manusia yang juga makhluk sosial akhirnya menimbulkan beberapa permasalahan baru terutama permasalahan mental pasien. Permasalahan ini tidak dapat diukur secara langsung, namun ikut berpengaruh dalam menyelamatkan nyawa pasien, permasalahan mental tersebut antara lain masalah psiko-sosial pasien $[3,4,12,18,20]$, masalah imunitas tubuh terhadap tingkat stress $[2,11,15,21]$, masalah keterbatasan perlakukan terhadap pasien ketika menggunakan robot dengan perbedaan kondisi sakit ringan sampai dengan kondisi kritis. Keluarga pasien dengan pasien kondisi kritis juga memerlukan penanganan berbeda, terutama ketika terbentur dengan masalah budaya dan agama [13]. Menemani pada detik-detik terakhir masa hidupnya merupakan salah satu kondisi yang berdampak besar terhadap anggota keluarga lainnya [8].

Desain robot ini dapat menyelesaikan beberapa permasalahan yang tidak terselesaikan oleh robot-robot yang telah digunakan saat ini. Salah satu permasalahan utama yang terjadi pada robot RAISA dan robot-robot telepresensi lainnya adalah kendala koneksi untuk mengontrol fungsifungsi didalamnya karena menggunakan koneksi Wi-Fi. Robot ini juga sekaligus membantu secara langsung dan tidak langsung untuk menyelesaikan permasalahan tenaga medis terhadap resiko penularan, keterbatasan APD yang dimiliki saat ini, mengurangi tingkat kelelahan tenaga medis akibat penggunaan APD level 3, ketidaknyamanan dalam menggunakan APD terutama APD level 3, kejenuhan pada tugas harian tenaga medis akibat repetisi pemakaian APD level 3 setiap hari, dapat dimasuki orang dengan tetap memiliki dimensi relatif kecil, dan dapat bergerak $360^{\circ}$ di lingkungan rumah sakit dan ruangan isolasi pasien tanpa mengubah desain ruangan yang ada di tiap rumah sakit. Dengan robot ini, berbagai kendala dapat diselesaikan dan pasien dapat ditemani secara langsung namun terbatas.

\section{METODE PENELITIAN}

Agar dapat menghadirkan orang yang dibutuhkan oleh pasien secara langsung, kami mendesain ruang pelindung di dalam robot dengan menggunakan metode antropometri. Metode yang digunakan untuk mendesain ruang pelindung memiliki kemiripan dengan desain ruang kokpit pesawat [17]. Desain tersebut dibuat untuk memfasilitasi $90 \%$ populasi potensial pilot dan meningkatkan ergonomi dari ruang kokpit pesawat dengan menggunakan metode antropometri dan data yang menyertainya. Pada desain kokpit juga diperlukan penyesuaian pengguna apabila akan digunakan untuk pengguna yang berbeda [1]. Dari penyesuaian tersebut, menghasilkan 704 dari 3000 orang tidak sesuai dengan kriteria. Agar tidak terjadi hal serupa, kami mencoba memperbaiki kriteria dalam desain ruang didalam ruang pelindung robot yang dibuat dengan melakukan asumsi pengambilan nilai terbesar dalam beberapa bagian pengukuran antropometri yang digunakan. Untuk pembuatan kursi, kami melakukan adopsi dari desain yang serupa dengan [6]. Pada desain tersebut, dikhususkan pada desain kursi yang sesuai dengan postur duduk. Seluruh elemen pendukung didalam postur duduk diikutsertakan agar memaksimalkan tingkat ergonomi kursi tersebut. Pada penelitian ini, kami hanya mengambil beberapa bagian penting dari postur duduk karena sebagai pendukung dari desain ruang didalam ruang pelindung robot, analisis terhadap kebutuhan motor penggerak yang digunakan, dan perbandingan biaya yang dikeluarkan antara penggunaan APD dengan penggunaan robot.

\section{HASIL DAN PEMBAHASAN}

Berdasarkan metode yang telah ditetapkan sebelumnya, rancangan tersebut dibagi menjadi empat bagian, yaitu pembuatan badan robot pelindung dengan metode antropometri, analisis kebutuhan motor penggerak, pelacakan posisi terakhir robot dengan menggunakan perpaduan GPS dan LPWAN, dan perbandingan biaya yang dikeluarkan antara penggunaan APD dengan robot.

\section{A. Rasio SA:V terkecil}

Untuk meminimalkan luasan area yang digunakan robot terhadap luasan area pada ruang isolasi, kami menggunakan Rasio Surface-area-tovolume terkecil (Rasio SA:V). Rasio SA:V tersebut didapatkan dengan membandingkan nilai dari luas area terhadap volume suatu benda. Beberapa kandidat SA:V yang digunakan dengan pertimbangan luas ruang isolasi ditunjukkan pada TABEL I.

Untuk mendapatkan nilai rasio yang sesuai akibat perbedaan nilai variabel, maka diperlukan penyamaan nilai variabel terlebih dahulu. Jika nilai variabel $r$ bernilai 0,5 . Nilai variabel $s$ sama dengan $2 r$. Nilai variabel $p$ dan $l$ pada balok sama dengan nilai variabel $s$, namun nilai variabel $t$ adalah dua kali nilai variabel $p$ atau $l$ atau $s$. Nilai $\pi$ adalah 3,14. Dari hasil penyamaan nilai variabel tersebut, didapatkan hasil bahwa nilai rasio SA:V per unit volume terkecil adalah kapsul. Untuk bentuk kapsul, tidak mungkin untuk diimplementasikan kedalam robot karena pada bagian bawah dan atas kapsul memiliki ruangan dengan volume setengah lingkaran. Untuk itu, dipilih bentuk yang lain 
namun masih pada posisi terdekat dari rasio SA:V kapsul, yaitu balok dan tabung tertutup.

\begin{tabular}{|l|l|l|l|l|c|}
\hline \multicolumn{7}{|c|}{ TABEL I. KOEFISIEN RASIO SA:V } \\
No & Bentuk & $\begin{array}{l}\text { Luas } \\
\text { Area } \\
\text { (SA) }\end{array}$ & $\begin{array}{l}\text { Vol. } \\
(\mathrm{V})\end{array}$ & $\begin{array}{c}\text { Rasio } \\
\text { SA:V } \\
\text { SA:V } \\
\text { per } \\
\text { unit } \\
\text { Vol. }\end{array}$ \\
\hline 1. & Kubus & $6 s^{2}$ & $s^{3}$ & $\frac{6}{s}$ & 6 \\
\hline 2. & Balok & $\begin{array}{l}2(p l \\
+p t \\
+l t)\end{array}$ & $p l t$ & $\frac{2(p l+p t+l t)}{p l t}$ & 10 \\
\hline 3. & Kapsul & $8 \pi r^{2}$ & $\frac{10 \pi r^{3}}{3}$ & $\frac{12}{5 r}$ & 12 \\
\hline 4. & $\begin{array}{l}\text { Tabung } \\
\text { Tertutup }\end{array}$ & $\begin{array}{l}2 \pi r(r) \\
+t)\end{array}$ & $\pi r^{2} t$ & $\frac{2(r+t)}{r t}$ & 5 \\
\hline 5. & Bola & $4 \pi r^{2}$ & $\frac{4}{3} \pi r^{3}$ & $\frac{3}{r}$ & 6 \\
\hline
\end{tabular}

TABEL II. PERHITUNGAN RASIO SA:V YANG BARU

\begin{tabular}{|l|l|c|c|c|}
\hline No & Bentuk & $\begin{array}{c}\text { Luas Area } \\
(\mathrm{SA})\end{array}$ & $\begin{array}{c}\text { Volume } \\
(\mathrm{V})\end{array}$ & $\begin{array}{c}\text { Rasio SA:V per } \\
\text { unit Volume }\end{array}$ \\
\hline 1. & Kubus & 6 & 1 & 6 \\
\hline 2. & Balok & 10 & 2 & 5 \\
\hline 3. & Kapsul & 6.26 & 1.308 & 4.785 \\
\hline 4. & $\begin{array}{l}\text { Tabung } \\
\text { Tertutup }\end{array}$ & 7.85 & 1.57 & 5 \\
\hline 5. & Bola & 3.14 & 0.523 & 6.003 \\
\hline
\end{tabular}

\section{B. Menghitung Berat Badan Ideal}

Langkah-langkah yang dilakukan adalah menghitung nilai tertinggi untuk berat badan ideal pada perempuan dan laki-laki di Indonesia dengan menggunakan BMI pada persamaan 1. Berat badan ideal berada pada nilai $18,5-24,9$. Nilai BMI ini dapat digunakan untuk usia 18-65 tahun.

$$
B M I=\frac{\text { Berat Badan }(\mathrm{kg})}{\text { Tinggi Badan } x \text { Tinggi Badan }\left(\mathrm{m}^{2}\right)}
$$

Berat badan ideal berasosiasi dengan kebiasaan hidup sehat yang sangat diperlukan oleh tenaga medis [8]. Berdasarkan data dari Kementerian Kesehatan, rerata tinggi badan masyarakat Indonesia untuk laki-laki sekitar $168 \mathrm{~cm}$ dan untuk perempuan sekitar $159 \mathrm{~cm}$. Dengan menggunakan persamaan (1), didapatkan berat badan ideal untuk kelompok laki-laki adalah $52,21 \mathrm{~kg}-70,27 \mathrm{~kg}$ dan $46,76 \mathrm{~kg}-62,95 \mathrm{~kg}$ untuk kelompok perempuan. Untuk memudahkan maka diambil nilai maksimal dengan pembulatan ke atas untuk berat badan ideal laki-laki adalah $70 \mathrm{~kg}$ dan 63 untuk perempuan.

\section{Pengukuran Antropometri Postur Tubuh}

Berdasarkan data dari Antropometri Indonesia yang dikeluarkan oleh Perhimpunan Ergonomi Indonesia dan Lab. Ergonomi dan Perancangan Sistem Kerja milik Lab Industri ITS Surabaya [7], didapatkan data antropometri yang diperlukan untuk mengecek ada tidaknya kesalahan dalam melakukan desain dan implementasi di dalam tabung robot. Data antropometri yang digunakan adalah 95th persentil atau 95\% mayoritas penduduk Indonesia. Untuk mencegah terjadinya kesalahan maka dilakukan perhitungan dengan menambahkan hasil nilai rerata ditambahkan dengan standar deviasi sehingga mendapatkan nilai minimal dan maksimal secara mutlak. Data antropometri yang dibutuhkan ditunjukkan pada Gambar 1 antara lain panjang lutut, tinggi popliteal, panjang popliteal, lebar pinggul, dan lebar sisi bahu yang ditampilkan dalam TABEL III.
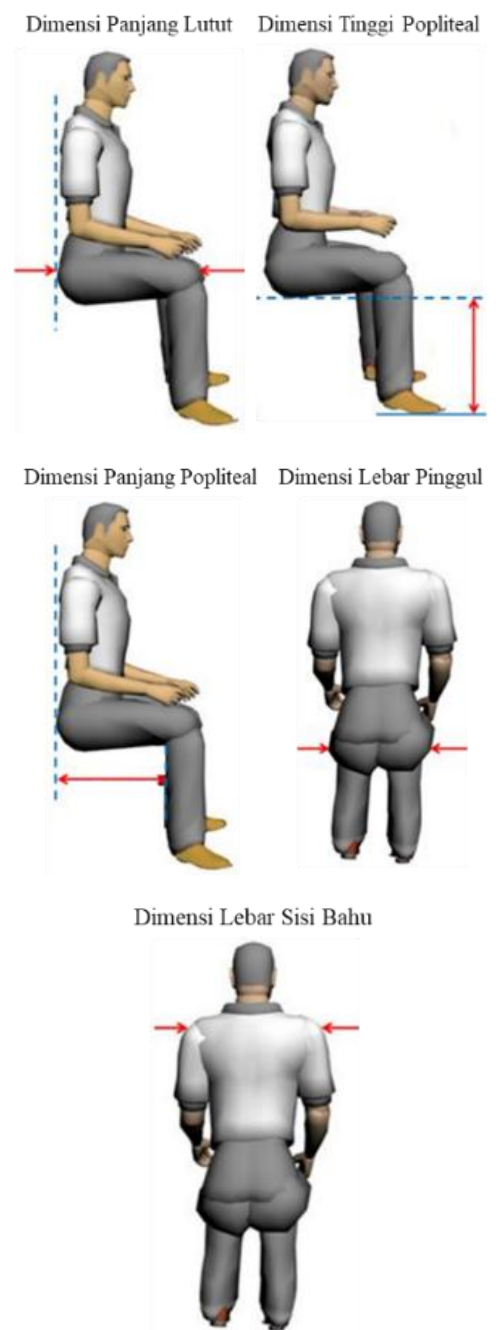

Gambar 1. Gambar Antropometri yang Digunakan untuk Menentukan Lebar Ruang di Dalam Tabung Robot

\section{Dimensi Kursi Ideal}

Untuk mendapatkan spesifikasi kursi yang sesuai, diperlukan data dari dimensi Panjang popliteal sebagai Panjang kursi, dimensi lebar pinggul sebagai lebar kursi, dan dimensi tinggi popliteal sebagai tinggi kursi. Dimensi kursi yang ideal berdasarkan data antropometri di TABEL III ditunjukkan pada TABEL IV. Untuk 
mempermudah pemilihan kursi, dapat menggunakan jenis kursi sesuai dengan pilihan nilai maksimum, minimum, dan rerata dari dimensi kursi ideal dari TABEL IV, atau menggunakan kursi berbentuk lingkaran dengan diameter $50 \mathrm{~cm}$ (dari pembulatan keatas nilai lebar kursi) dan tinggi $50 \mathrm{~cm}$ (dari pembulatan kebawah nilai tinggi kursi).

\section{E. Pelindung Lapisan Pertama}

Pada pelindung lapisan pertama menggunakan bahan dari Polikarbonat padat. Polikarbonat memiliki keunggulan antara lain:

1. Bening seperti kaca

2. Untuk ketebalan yang sama, polikarbonat 250 kali lebih kuat daripada kaca dan 30 kali lebih kuat daripada akrilik

3. Permukaan datar dan halus

4. Tidak mengalami kebocoran

5. Tahan terhadap benturan keras

6. Fleksibel dan mudah digunakan

7. Tidak membutuhkan banyak dukungan structural karena ringan

8. Proteksi sinar UV dan cuaca

9. Kedap suara

Polikarbonat memiliki ketebalan beragam hingga $10 \mathrm{~mm}$. Pada umumnya, dimensi polikarbonat memiliki panjang $122 \mathrm{~cm}$ dan lebar $244 \mathrm{~cm}$ dan berat $1,2 \mathrm{~g} / \mathrm{cm}^{3}$. Dikarenakan berbentuk tabung, diperlukan perhitungan kebutuhan lembar polikarbonat padat untuk membuat tabung lapisan pertama paling luar. Namun perlu diingat bahwa polikarbonat padat tersebut digunakan masingmasing untuk luas setengah selimut tabung dengan luasan tersebut pada persamaan 2 .

$$
\pi r t=\pi \times 0,5 \times 2=3,14 \mathrm{~m}^{2}
$$

Jika luas persegi panjang sama dengan luas selimut tabung, dengan nilai $l=t$ dan dengan nilai minimal $r=0,35 m$ didapatkan persamaan 3 dan 4

$$
\begin{aligned}
& p l=\pi r t \\
& p=\pi r
\end{aligned}
$$

maka, didapatkan nilai p sebesar 1,099m. Dapat diambil kesimpulan bahwa polikarbonat padat dapat menggunakan yang berukuran $122 \mathrm{~cm} \mathrm{x}$ $244 \mathrm{~cm}$.

Berdasarkan persamaan 4, jika $p=122 \mathrm{~cm}$, maka nilai $r$ yang didapatkan adalah nilai $r$ maksimal yaitu $38,85 \mathrm{~cm}$ atau dibulatkan menjadi $38 \mathrm{~cm}$ atau berdiameter $76 \mathrm{~cm}$. Dengan ukuran panjang lutut $69,49 \mathrm{~cm}$ dibulatkan keatas menjadi $70 \mathrm{~cm}$ menjadi nilai diameter lingkaran minimal untuk tempat duduk dan masih ada sisa jarak sekitar $6 \mathrm{~cm}$ dengan jarak panjang lutut saat duduk. Sisa jarak $6 \mathrm{~cm}$ tersebut dapat digunakan untuk menempatkan pelindung kedua dengan bahan zincalum. Untuk membuat lengkungan sempurna dari setengah tabung tersebut, diperlukan persamaan 5 untuk memilih ketebalan polikarbonat padat yang sesuai dan ditunjukkan bentuk lengkungannya seperti pada Gambar 2.

\begin{tabular}{|c|l|c|c|c|}
\multicolumn{5}{|c|}{ TABEL III. DATA ANTROPOMETRI INDONESIA } \\
\hline No & Data dari & $\begin{array}{c}\text { Nilai } \\
95 \text { th } \\
(\mathrm{cm})\end{array}$ & $\begin{array}{c}\text { Std. } \\
\text { Deviasi } \\
(\mathrm{cm})\end{array}$ & $\begin{array}{c}\text { Nilai Maks. } \\
(\mathrm{cm})\end{array}$ \\
\hline 1. & Panjang Lutut & 62,08 & 7,41 & 69,49 \\
\hline 2. & $\begin{array}{l}\text { Tinggi } \\
\text { Popliteal }\end{array}$ & 49,1 & 5,49 & 54,59 \\
\hline 3. & $\begin{array}{l}\text { Panjang } \\
\text { Popliteal }\end{array}$ & 49,65 & 5,94 & 55,59 \\
\hline 4. & Lebar Pinggul & 43 & 6,49 & 49,49 \\
\hline 5. & $\begin{array}{l}\text { Lebar Sisi } \\
\text { Bahu }\end{array}$ & 51,16 & 7,54 & 58,70 \\
\hline
\end{tabular}

TABEL IV. DIMENSI KURSI YANG IDEAL

\begin{tabular}{|c|l|c|c|c|}
\hline No & $\begin{array}{c}\text { Dimensi } \\
\text { Kursi Ideal }\end{array}$ & $\begin{array}{c}\text { Nilai } \\
\text { Maksimum } \\
(\mathrm{cm})\end{array}$ & $\begin{array}{c}\text { Nilai } \\
\text { Minimum } \\
(\mathrm{cm})\end{array}$ & $\begin{array}{c}\text { Nilai } \\
\text { Rerata } \\
(\mathrm{cm})\end{array}$ \\
\hline 1. & $\begin{array}{l}\text { Panjang } \\
\text { Kursi }\end{array}$ & 55,59 & 49,65 & 52,62 \\
\hline 2. & Lebar Kursi & 49,49 & 43 & 46,25 \\
\hline 3. & Tinggi Kursi & 54,59 & 49,1 & 51.85 \\
\hline
\end{tabular}

$$
T_{\min }=\frac{d_{\min }}{100}
$$

keterangan:

$\mathrm{T}_{\text {min }}=$ tebal minimal polikarbonat padat $(\mathrm{mm})$ $\mathrm{d}_{\min }=$ diameter minimal lengkungan tabung $(\mathrm{mm})$ sehingga didapatkan nilai ketebalan sebesar 7,6mm atau dibulatkan menjadi $7.5 \mathrm{~mm}$ atau dijadikan pembulatan kebawah menjadi $7 \mathrm{~mm}$. Ketiga pilihan tersebut bergantung kepada ketersediaan ketebalan yang ada di pasaran.

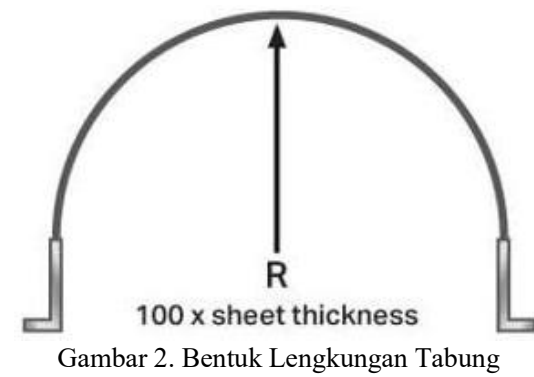

Untuk sepasang sambungan berbentuk huruf $\mathrm{H}$ berwarna merah pada Gambar 3 diletakkan pada sebelah sisi kanan dan kiri tabung. Sambungan $\mathrm{H}$ tersebut disarankan menggunakan jenis alumunium dengan ketebalan $5 \mathrm{~mm}$ untuk menahan tekanan lengkungan dengan berat $0,15 \mathrm{~kg} / \mathrm{m}$. Pada Gambar 3 , dibagian atas gambar terdapat bentuk $\mathrm{H}$ memanjang yang digunakan sebagai pintu untuk tempat keluar masuk orang dari dalam keluar dan sebaliknya. 


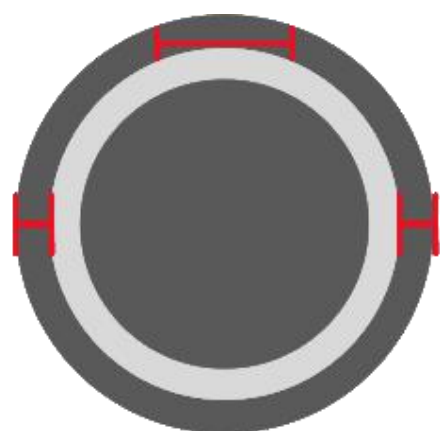

Gambar 3. Peletakan Titik Sambungan Berbentuk H

\section{F. Pelindung Lapisan Kedua}

Pada pelindung lapisan kedua menggunakan bahan dari Zincalume. Beberapa alasan menggunakan pelindung lapis kedua adalah diperlukan penutup akibat adanya disinfeksi dengan menggunakan sinar UV, dan sinar UV memiliki sifat tidak dapat menembus bahan yang cahaya biasa tidak dapat menembusnya. Selain itu, diperlukan bahan yang tidak tembus cahaya namun bersifat fleksibel, kuat, dan tahan lama penggunaannya.

Jenis zincalume yang digunakan adalah G550 dengan berat $7,85 \mathrm{~g} / \mathrm{cm}^{3}$, ketebalan $0,5 \mathrm{~mm}$ dipotong selebar $1230 \mathrm{~mm}$ dan sepanjang $2 \mathrm{~m}$ menyesuaikan dimensinya dengan pelindung lapisan pertama. Dibutuhkan sepasang tiang penyangga untuk melakukan penutupan saat diperlukan ketika melewati area sterilisasi dengan sinar UV. Tiang penyangga tersebut menggunakan sepasang baja beton SNI polos dan berdiameter $14 \mathrm{~mm}$ sepanjang $2024 \mathrm{~mm}$ dengan berat total $2,42 \mathrm{~kg}$ yang sekaligus sebagai tiang tempat menyimpan roll zincalume saat tidak digunakan.

Zincalum sepanjang $2024 \mathrm{~mm}$ ini, selisih $24 \mathrm{~mm}$ didapatkan dari penambahan karena menggunakan 4 buah ball bearing masing-masing yang dipasang dikanan kiri pada bagian lantai dan atap dari setiap ujung tiang penyangga, sehingga dibutuhkan dua kali tebal dari setiap ball bearing. ball bearing yang digunakan adalah ball bearing dengan diameter dalam $15 \mathrm{~mm}$, diameter luar $37 \mathrm{~mm}$, tebal $12 \mathrm{~mm}$.

Untuk menarik roll zincalum tersebut digunakan mekanisme rolling door agar dapat dengan mudah melakukan penarikan rol zincalum tersebut dari satu tiang penyangga ke tiang penyangga yang lain. Untuk membuat jalur menyerupai rolling door pada bagian lantai dan atap, digunakan 4 buah ball bearing berdiameter dalam $8 \mathrm{~mm}$, diameter luar $16 \mathrm{~mm}$ dan tebal $5 \mathrm{~mm}$ dan dengan melubangi lantai dan atap tabung selebar tebal ball bearing yang digunakan. Tiang rolling door menggunakan sepasang beton baja polos SNI berdiameter $8 \mathrm{~mm}$ dengan total berat adalah $0,79 \mathrm{~kg}$.

\section{G. Spesifikasi Tabung Oksigen}

Agar mendapatkan suplai oksigen yang mencukupi karena tertutup rapat dari udara luar, maka diperlukan bantuan dari penggunaan tabung oksigen. Untuk menentukan ukuran tabung oksigen yang digunakan, tabung oksigen diletakkan disebelah kanan atau kiri dari kursi setelah ditambah angka maksimal $50 \mathrm{~cm}$ dari lebar kursi. Ukuran tabung oksigen yang dapat digunakan harus berdiameter dibawah $20 \mathrm{~cm}$ agar tidak melebihi titik maksimal panjang lutut atau setara dengan diameter maksimal tabung.

Pada TABEL V ditunjukkan ukuran dari tabung oksigen yang dapat digunakan. Meskipun dapat menggunakan ukuran tabung oksigen $6 \mathrm{~m}^{3}$, namun tidak disarankan karena selain melebihi nilai maksimal dari panjang lutut, juga sangat mendekati dengan nilai diameter maksimal tabung pada lapisan terluar, memiliki berat mendekati berat badan ideal perempuan indonesia, dan dapat mengganggu pergerakan dari mekanisme rolling door. Oleh karena itu, disarankan menggunakan tabung oksigen berukuran maksimal $2 \mathrm{~m}^{3}$.

Untuk mengetahui daya tahan tabung oksigen antara ukuran tabung terhadap penggunaan angka regulator, berdasarkan TABEL VI tentang hubungan angka regulator terhadap waktu penggunaan tabung sampai habis, dengan menggunakan tabung berukuran $2 \mathrm{~m}^{3}$ dapat memberikan kesempatan kepada tenaga medis untuk berdiam didalamnya selama maksimal 8 jam.

TABEL V. UKURAN TABUNG OKSIGEN

\begin{tabular}{|l|l|l|l|l|}
\hline $\begin{array}{c}\text { Ukuran } \\
\text { tabung }\end{array}$ & $\begin{array}{c}\text { Tinggi } \\
\text { tabung }\end{array}$ & $\begin{array}{c}\text { Diameter } \\
\text { tabung }\end{array}$ & $\begin{array}{c}\text { Keliling } \\
\text { tabung }\end{array}$ & Berat isi \\
\hline $0,5 \mathrm{~m}^{3}$ & $40 \mathrm{~cm}$ & $11 \mathrm{~cm}$ & $35 \mathrm{~cm}$ & $5 \mathrm{~kg}$ \\
\hline $1 \mathrm{~m}^{3}$ & $64 \mathrm{~cm}$ & $14 \mathrm{~cm}$ & $45 \mathrm{~cm}$ & $10 \mathrm{~kg}$ \\
\hline $1,5 \mathrm{~m}^{3}$ & $78 \mathrm{~cm}$ & $17 \mathrm{~cm}$ & $54 \mathrm{~cm}$ & $15 \mathrm{~kg}$ \\
\hline $2 \mathrm{~m}^{3}$ & $99 \mathrm{~cm}$ & $16,5 \mathrm{~cm}$ & $52 \mathrm{~cm}$ & $20 \mathrm{~kg}$ \\
\hline $6 \mathrm{~m}^{3}$ & $143 \mathrm{~cm}$ & $22 \mathrm{~cm}$ & $70 \mathrm{~cm}$ & $60 \mathrm{~kg}$ \\
\hline
\end{tabular}

TABEL VI. PERBANDINGAN ANGKA REGULATOR TERHADAP WAKTU KONSUMSI OKSIGEN

\begin{tabular}{|c|c|c|c|c|c|c|}
\hline \multirow{2}{*}{$\begin{array}{c}\text { Ukuran } \\
\text { tabung }\end{array}$} & \multicolumn{6}{|c|}{ Angka Regulator terhadap waktu (jam) } \\
\cline { 2 - 7 } & 2 & 4 & 6 & 8 & 10 & 12 \\
\hline $0,5 \mathrm{~m}^{3}$ & 2 & 1 & 0,5 & - & - & - \\
\hline $1 \mathrm{~m}^{3}$ & 4 & 2 & 1 & 0,5 & - & - \\
\hline $1,5 \mathrm{~m}^{3}$ & 6 & 4 & 2 & 1 & - & - \\
\hline $2 \mathrm{~m}^{3}$ & 8 & 6 & 4 & 2 & 1 & 0,5 \\
\hline $6 \mathrm{~m}^{3}$ & 24 & 12 & 6 & 3 & 1,5 & 0,75 \\
\hline
\end{tabular}

\section{H. Lantai dan Atap Tabung}

Lantai dan atap tabung menggunakan bahan dari multipleks ketebalan $18 \mathrm{~mm}$ dan berjari-jari $80 \mathrm{~cm}$. Multipleks dipilih karena kekuatan menahan beban, ketahanan lebih terhadap air, dan mudah didapatkan dipasaran. Seperti pada Gambar 4, pada bagian abu-abu adalah daerah yang dibuatkan jalur untuk rolling door dengan ball bearing pada 
lapisan pelindung kedua dengan ketebalan $5 \mathrm{~mm}$ dan diameter luar $16 \mathrm{~mm}$. Untuk setiap meternya memiliki berat sekitar $0,67 \mathrm{~kg} / \mathrm{m}^{2}$, sehingga estimasi total berat maksimal untuk setiap bagian multipleks yang menggunakan persamaan 6

$$
W_{t}=\sum_{i=1}^{n} w_{m_{i}}\left(\pi r^{2}\right)
$$

keterangan:

$W_{t}=$ Berat setiap multipleks $(\mathrm{kg})$

$r \quad=$ jari-jari lingkaran $(\mathrm{m})$

$w_{m}=$ Berat jenis multipleks $\left(\mathrm{kg} / \mathrm{m}^{2}\right)$

yaitu sebesar $1,346 \mathrm{~kg} / \mathrm{m}^{2}$ untuk tiap lapisannya.

Untuk masing-masing lantai dan atap jika menggunakan satu lapis multipleks $18 \mathrm{~mm}$, total berat yang akan dihasilkan adalah

$$
W_{t}=W_{t_{1}}+W_{t_{2}}
$$

atau sekitar 2,692kg. Jika menggunakan dua lapis menghasilkan berat dua kali lebih besar atau sekitar $5,385 \mathrm{~kg}$. Untuk faktor keamanan dan kekuatan menahan beban, disarankan menggunakan dua lapisan dari Gambar 4.

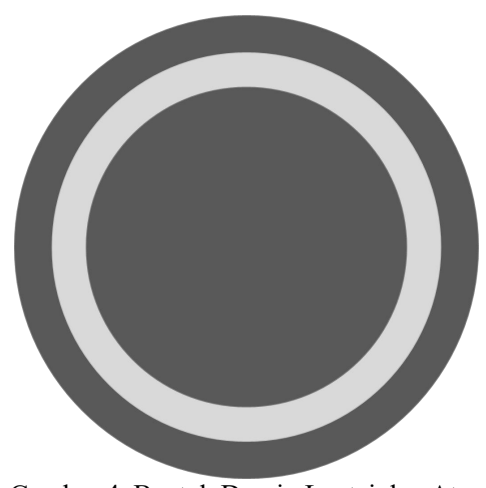

Gambar 4. Bentuk Desain Lantai dan Atap

\section{Area Penopang Tabung}

Untuk memperkuat tabung agar tidak mengalami masalah keseimbangan selama digunakan, diperlukan pengaman yang mudah dicek dan diperbaiki menggunakan baut berbentuk $\mathrm{U}$ pada sisi lingkaran terluar. Baut $U$ merupakan baut dengan komposisi Carbon Steel, Zinc Plated, Hot Dipped Galvanized, dan 304 Stainless Steel. Untuk mendapatkan baut $U$ yang sesuai dapat menggunakan rujukan standar dari baut U. Bentuk dari baut $U$ ditunjukkan pada Gambar 5a, sedangkan bentuk penopang bawah tempat peletakan baut $U$ dari area tabung ditunjukkan pada Gambar 5b yang berwarna jingga.

Pada area penopang tabung yang berwarna biru, digunakan besi baja sirip berukuran $19 \mathrm{~mm}$ dan panjang sirip $1 \mathrm{~mm}-1,9 \mathrm{~mm}$, maka baja memiliki diameter maksimal $20,9 \mathrm{~mm}$ dan berat baja $2,23 \mathrm{~kg}$ per meter. Jumlah batang baja yang diperlukan adalah $90 \mathrm{~cm}$ sebanyak 4 buah. Total berat yang dihasilkan adalah

$$
W_{a}=\sum_{i=1}^{n} L_{i}\left(\frac{X_{i}}{100}\right) W_{b_{i}}
$$

dengan $L i$ adalah banyak setiap batang baja yang digunakan, $X i$ adalah panjang setiap baja yang digunakan, $W_{b_{i}}$ adalah kilogram berat setiap baja per meter didapatkan berat sebesar $8,028 \mathrm{~kg}$.

Untuk mendapatkan nilai yang sesuai dari baut $U$ yang akan digunakan, diperlukan kesesuaian komponen pada Gambar 5a. Penyesuaian tersebut antara lain nilai C, D, L, dan T. Dengan jarak sekitar $55 \mathrm{~mm}$ dari ujung teratas lantai sampai ujung terbawah baja beton yang saling menempel, diperlukan nilai $\mathrm{L}$ melebihi $55 \mathrm{~mm}$. Selain itu, nilai $\mathrm{C}$ yang diperlukan harus diatas $21 \mathrm{~mm}$ untuk menghindari kesalahan diameter baja beton. Oleh karena itu, spesifikasi Baut $\mathrm{U}$ yang diperlukan adalah $\mathrm{L}>55 \mathrm{~mm}$ dan $\mathrm{C}>21 \mathrm{~mm}$. Berdasarkan standar baut $U$, didapatkan baut $U$ yang sesuai adalah dua tipe baut. Baut pertama dengan standar nilai $\mathrm{D}=1 / 4-20$ inchi, nomor baut $\mathrm{U}$ adalah $7, \mathrm{~L}=2$ $3 / 4$ inchi, $\mathrm{C}=1 \frac{1}{2}$ inchi, dan $\mathrm{T}=13 / 8$ inchi. Baut kedua dengan standar nilai $\mathrm{D}=3 / 8-16$ inchi, nomor baut $\mathrm{U}$ adalah $19, \mathrm{~L}=2 \frac{1}{2}$ inchi, $\mathrm{C}=1 \frac{1}{2}$ inchi, dan $\mathrm{T}=1 \frac{1 / 4}{4}$ inchi. Selain itu, dua standar baut $\mathrm{U}$ tadi, tidak melebihi batas terluar dari area pada Gambar 5 b untuk daerah pemasangan baut.

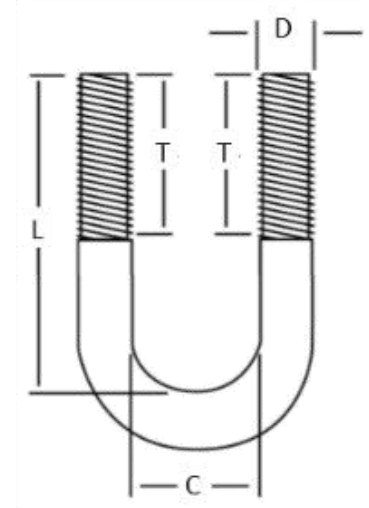

(a)

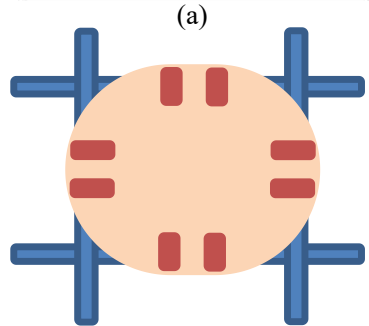

(b)

Gambar 5. (a). Bentuk Baut U yang digunakan (b). Area Penopang tabung 


\section{J. Model Akhir Desain Tabung Robot}

Model akhir dari desain akhir robot dibuat dengan menggunakan acuan SA:V terkecil ditunjukkan pada Gambar 8. Bagian lingkaran hitam adalah pelindung lapisan pertama dan bagian abu-abu adalah pelindung lapisan kedua. Tabung oksigen ditunjukkan dengan lingkaran warna kuning. Kursi ditunjukkan dengan kotak warna kecoklatan. Lingkaran biru merupakan roda rolling door pada bagian lantai dan atap tabung, diperjelas pada Gambar 10 yang berwarna oranye.

Dua lingkaran putih adalah tempat meletakkan sarung tangan latex panjang hingga siku yang dibungkus dengan karet pneumatic agar kedap udara dan diperjelas pada Gambar 10. Pada Gambar 10, penempatan sarung tangan latex tersebut dibagi menjadi tiga bagian agar dapat menjangkau daerah diatas kepala, sejajar dengan dada, dan menjangkau saat jongkok. Untuk menutup rapat celah-celah sambungan yang ada pada tiap bagian, digunakan silicon seal tipe heavy duty.

TABEL VII. TOTAL BERAT TABUNG

\begin{tabular}{|l|l|l|}
\hline No & Keterangan & Berat $(\mathrm{kg})$ \\
\hline 1. & Beban tubuh ideal & 70 \\
\hline 2. & Kursi 50cm (estimasi) & 5 \\
\hline 3. & 2xPolikarbonat padat & 4,1 \\
\hline 4. & 2xSambungan H & 0,3 \\
\hline 5. & 2xTiang penyangga 1 & 2,42 \\
\hline 6. & 2xTiang Penyangga 2 & 0.79 \\
\hline 7. & 2xZincalum roll & 0,19154 \\
\hline 8. & Atap dan lantai 2 lapis & 5,385 \\
\hline 9. & Baja penopang terbawah & 8,028 \\
\hline 10. & Tabung oksigen & 20 \\
\hline \multicolumn{2}{|l|}{ Total Berat Kosong Tabung } & 45.21454 \\
\hline \multicolumn{2}{|l|}{ Total Berat Bermuatan Tabung } & 115.21454 \\
\hline
\end{tabular}

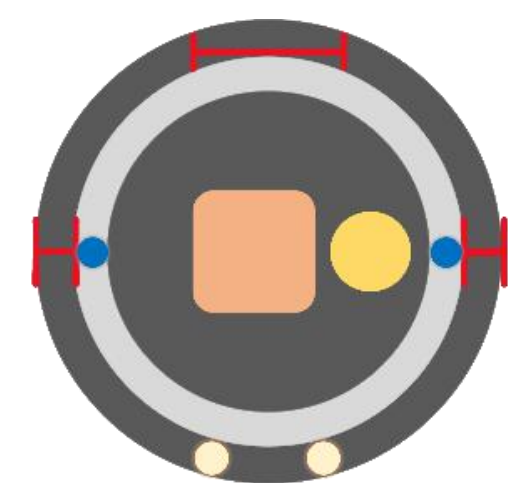

Gambar 8. Penampang Tabung Dilihat dari Atas

Pada Gambar 9, berdasarkan nilai antropometri tubuh pada TABEL III diberi sebuah pintu tanpa engsel pintu yang berdimensi $50 \mathrm{~cm} \mathrm{x}$ $150 \mathrm{~cm}$ untuk digunakan sebagai pintu masuk. Pintu tersebut diberikan pengaman gerendel berukuran 3 inci ditandai dengan warna hijau, dan ditutup celah udara yang terjadi pada bagian dalam dan luar tabung dengan menggunakan $3 \mathrm{M}$ duct tape heavy duty. Masing-masing area yang ditutup dengan duct tape memiliki panjang minimal 4 meter. Untuk mengetahui total berat dari desain tabung yang dibuat disajikan pada TABEL VII.

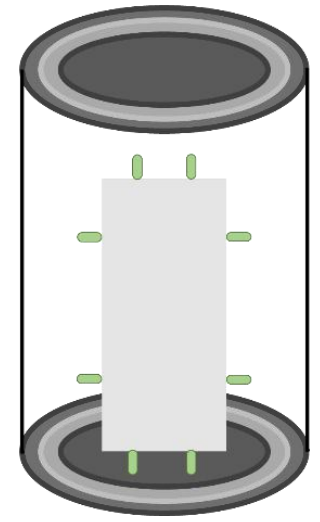

(a)

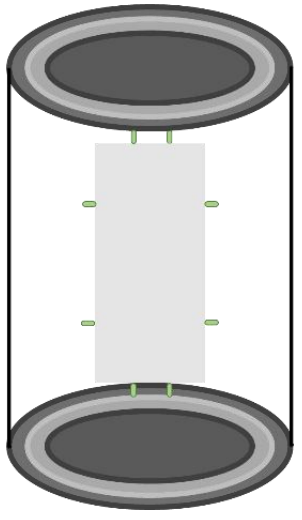

(b)
Gambar 9. (a). Tampak Belakang Tabung (b). Tampak Depan Tabung

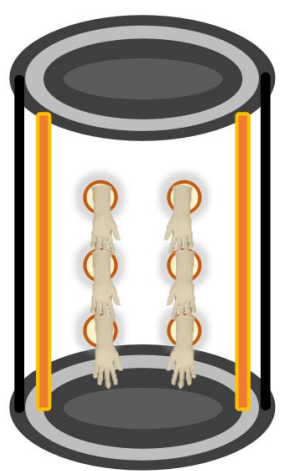

Gambar 10. Posisi Peletakan Sarung Tangan Latex

\section{K. Pelacakan Posisi Robot}

Untuk mengetahui posisi terakhir robot, diperlukan mekanisme pelacakan dengan menggunakan teknologi Global Positioning System (GPS) dan data ditransmisikan dengan menggunakan Low-Power Wide-Area Network (LPWAN). GPS digunakan untuk mengetahui posisi robot dengan presisi dengan menggunakan informasi posisi saat ini relatif dengan posisi satelit yang berhasil ditangkap sinyalnya. Selain itu, dengan menggunakan GPS UBLOX NEO 6M, tidak hanya ketelitian selisih lokasi maksimal hingga 2meter yang didapatkan namun juga mendapatkan informasi ketinggian robot, sehingga informasi ini secara akurat dapat memetakan posisi dan lokasi robot lebih akurat dalam posisi dimensi tiga.

Alasan penggunaan LPWAN adalah salah satu teknologi komunikasi nirkabel pada jaringan pita lebar untuk berkomunikasi jarak jauh dengan memanfaatkan bitrate rendah untuk dapat menerima lebih dari ratusan perangkat sensor untuk setiap detik, dapat beroperasi hingga jarak $15 \mathrm{~km}$, konsumsi daya rendah, dan relatif murah untuk tiap 
sensor yang dipasang. Untuk perangkat yang digunakan pada LPWAN ini adalah Long-Range (LoRa).

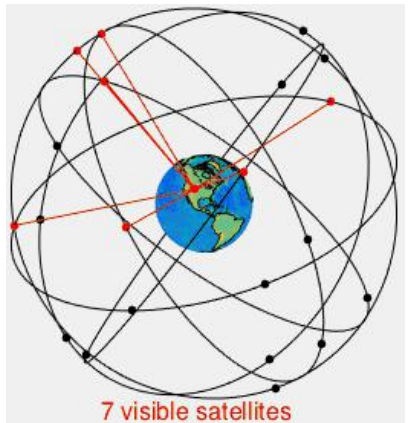

Gambar 6. Jumlah Satelit yang Diperlukan untuk Tingkat Akurasi GPS yang Digunakan

Berdasarkan Tabel Alokasi Spektrum Frekuensi Radio Indonesia, Indonesia berada di REGION 3 yang berimbas pada penggunaan teknologi harus mengikuti frekuensi yang telah disepakati di wilayah tersebut. Dari aturan tersebut, INS12, INS15 dan INS16 merupakan daerah dimana LoRa akan melakukan interferensi dengan spektrum pita lebar milik radio telekomunikasi komersial yang ada di Indonesia jika menggunakan frekuensi standar. Namun, terdapat 1 frekuensi LoRa yang berlisensi bebas, yaitu dengan menggunakan frekuensi disekitar $920 \mathrm{MHz}$ untuk Uplink dan Downlink dengan Base station yang dimiliki oleh LoRa. Dengan frekuensi ini, kecepatan dan kualitas data lebih terjamin karena tidak mengalami interferensi dan tidak melanggar peraturan pembagian tabel spektrum frekuensi.

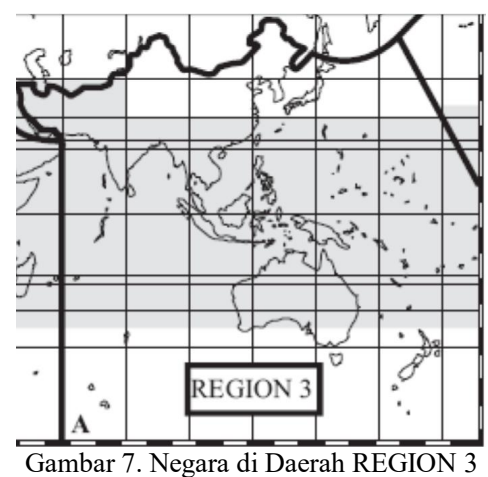

\section{Pemilihan Roda Robot}

Pertimbangan utama dalam pemilihan roda robot yang digunakan pada penelitian ini adalah area ruangan yang sempit dan membutuhkan kelincahan tersendiri dalam melakukan manuver di ruang sempit dengan sudut manuver yang kecil. Untuk memenuhi kebutuhan tersebut, dipilihlah jenis roda dengan sudut manuver terkecil, dan didapatkanlah roda dengan jenis omnidirectional wheel atau roda yang dapat bergerak bebas kearah manapun, salah satunya adalah Mecanum Wheel.

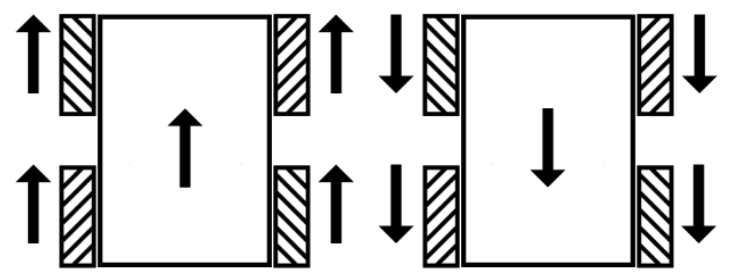

(a)

(b)

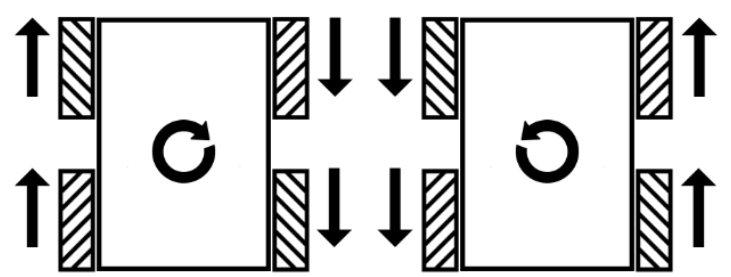

(c)

(d)

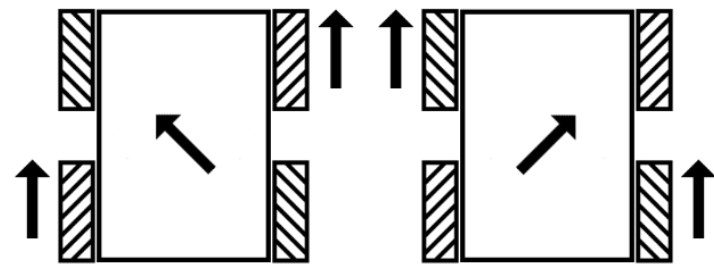

(e)

(f)

Gambar 8. Pergerakan Roda Mecanum dalam Berbagai Cara (a) Maju, (b) Mundur, (c) Rotasi Searah Jarum Jam, (d) Rotasi Berlawanan Jarum Jam, (e) Diagonal ke Kiri, (f) Diagonal ke Kanan

Cara kerja dari mecanum wheel ini dijelaskan pada Gambar 8. Roda mecanum merupakan roda yang bekerja dengan cara bergerak dengan sudut $45^{\circ}$ untuk setiap rodanya. Begitu juga dengan pemasangan roda mecanum dipasang dengan konfigurasi berbeda, saling berapasangan diagonalnya. Sisi kiri atas berpasangan dengan sisi kanan bawah, dan sisi kanan atas berpasangan dengan kiri bawah. Untuk mendapatkan pergerakan, ada beberapa hal yang harus dilakukan, antara lain:

1. Pada gerakan maju (a), keempat roda bergerak maju secara bersama-sama

2. Pada gerakan mundur (b), keempat roda bergerak mundur secara bersama-sama

3. Pada gerakan rotasi searah jarum jam (c), semua roda dikiri bergerak maju dan semua roda dikanan bergerak mundur.

4. Pada gerakan rotasi berlawanan jarum jam (d), semua roda dikanan bergerak maju dan semua roda dikiri bergerak mundur.

5. Pada gerakan diagonal kekiri (e), roda kanan atas dan kiri bawah bergerak maju secara bersama-sama

6. Pada gerakan diagonal kekanan (f), roda kiri atas dan kanan bawah bergerak maju secara bersama-sama 


\section{Motor Penggerak Tabung Robot}

Untuk menggerakkan beban maksimal seberat $200 \mathrm{~kg}$ sesuai dengan kemampuan roda mecanum yang digunakan, diperlukan motor penggerak dengan motor yang digunakan adalah motor stepper DC. Alasan pemilihan motor stepper adalah kemudahan dalam mengendalikan pergerakan dan kecepatan hingga ketelitian rotasi sebesar $1^{0}$ dengan jarak perpindahan bergantung dengan diameter roda mecanum yang digunakan.

Untuk itu, dibutuhkan torsi mesin yang sesuai agar dapat menggerakkan robot tanpa membebani motor terlalu besar. Nilai gaya gesek ini didapatkan secara estimasi berdasarkan koefisien gesek pada jalan kasar [19], meskipun pada kenyataannya lantai rumah sakit berlantai licin, namun tidak tersedia data gaya geseknya, sehingga nilai gaya gesek saat ini akan lebih besar daripada nilai gaya gesek pada lantai rumah sakit. Dengan melakukan regresi linear dari beban $68 \mathrm{~kg}$, menghasilkan gaya gesek sebesar 0,60 , beban $68 \mathrm{~kg}$ dibagi 2 menghasilkan estimasi nilai gaya gesek sebesar 0,53 dan beban 68 dikali 2 mendapatkan nilai gaya gesek sebesar 0,75 . Dari hasil regresi, didapatkan nilai untuk beban $200 \mathrm{~kg}$ menghasilkan estimasi nilai gaya gesek sebesar 0,89. Nilai $r$ didapatkan dari setengah kali diameter roda atau sebesar $127 \mathrm{~mm}$. Nilai torsi didapatkan dari persamaan

$$
\begin{aligned}
& F t=m g \mu \\
& F=0,25 F t \\
& \tau=F r
\end{aligned}
$$

Keterangan:

$\mathrm{F}_{\mathrm{t}}=$ gaya total untuk keempat roda $(\mathrm{N})$

$\mathrm{F}=$ gaya tiap roda $(\mathrm{N})$

$\tau=$ torsi $(\mathrm{Nm})$

$\mathrm{m}=\operatorname{massa}(\mathrm{kg})$

$\mathrm{g}=$ gravitasi $(\mathrm{m} / \mathrm{s})$

$\mu=$ koefisien gaya gesek

$\mathrm{r}=$ jari-jari roda mecanum $(\mathrm{m})$

Dari hasil perhitungan, didapatkan nilai $\tau$ sebesar 56,515Nm. Untuk mengurangi kebutuhan torsi motor, diberikan gear dengan perbandingan gear roda dengan gear motor seperti pada Gambar 9.

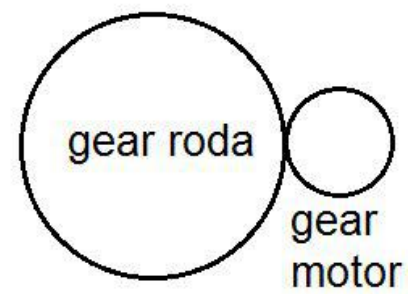

Gambar 9. Perbandingan Gear pada Robot
Untuk mendapatkan perbandingan yang sesuai dengan nilai torsi motor yang lebih kecil, digunakan perbandingan gear roda dengan gear motor menggunakan perbandingan 5:1 berdasarkan perbandingan antara jumlah gigi roda dengan jumlah gigi motor menggunakan jumlah gigi 50:10. Motor yang digunakan minimal memiliki torsi sebesar $\frac{56,515}{5}$ atau sebesar 11,303 Nm, sehingga dengan kemampuan torsi motor sebesar $12 \mathrm{Nm}$ sudah mampu menggerakkan robot ini. Untuk motor penggerak, digunakan motor stepper dari NEMA42 Stepper Motor 21Nm. Torsi maksimum yang dihasilkan adalah $21 \mathrm{Nm}$, sehingga dengan kebutuhan torsi yang diberikan akan mampu menggerakkan robot dengan hanya $57,14 \%$ dari total kemampuan motor.

\section{N. Baterei dan Konsumsi Daya}

Untuk menggerakkan motor, dibutuhkan catu daya dalam bentuk baterei. Ketika baterei telah habis arusnya, baterei bisa diisi ulang atau diganti dengan baterei sejenis secara hot-swap. Baterei yang digunakan adalah baterei pack LiFe PO4 12V $40 \mathrm{Ah}$. Baterei yang digunakan sejumlah 8 baterei dengan konfigurasi 4 seri 2 paralel sehingga total menghasilkan tegangan $48 \mathrm{~V}$ dengan kapasitas $80 \mathrm{Ah}$.

Dengan kemampuan baterei tersebut, konsumsi daya pada motor pada saat beban puncak adalah pada saat keempat motor berjalan pada arus maksimum. Besar konsumsi daya pada tiap motor jika berada pada arus maksimum adalah sebesar 5 Ampere, sehingga total arus yang dibutuhkan keempat motor adalah 20 Ampere. Maka dengan kapasitas baterai $80 \mathrm{Ah}$, robot dapat dioperasikan selama 4 jam pada daya maksimum dalam sekali pengisian. Perlu dicatat bahwa dalam praktik sebenarnya, motor tidak selalu berada pada kondisi daya maksimum, sehingga durasi penggunaan bisa lebih dari 4 jam dalam sekali pengisian.

\section{O. Kontrol Motor pada Arduino}

Proses kendali pada motor, dilakukan ujicoba diarduino dengan menggunakan Arduino IDE. Kode program untuk melakukan kontrol pergerakan seperti pada gambar XX, tercantum pada algoritma 1. Untuk Pengendalian tersebut, digunakan joystick untuk mengendalikan pergerakan robot. Nilai luaran yang dihasilkan dari joystick nantinya akan menjadi nilai pengatur kecepatan pada fungsi wheelSpeed pada setiap bagian roda. LeftFrontWheel mengacu kepada roda mecanum pada bagian kiri atas. LeftBackWheel mengacu kepada roda mecanum pada bagian kiri bawah. RightFrontWheel mengacu kepada roda mecanum pada bagian kanan atas, dan 
RightBackWheel mengacu kepada roda mecanum pada bagian kanan bawah.

1. void moveForward() \{

2. LeftFrontWheel.setSpeed(wheelspeed);

3. LeftBackWheel. setSpeed(wheelspeed);

4. RightFrontWheel.setSpeed(wheelspeed);

5. RightBackWheel.setSpeed(wheelspeed);

6. \}

7. void moveBackward () \{

8. LeftFrontWheel. setSpeed (-wheelspeed);

9. LeftBackWheel. setSpeed (-wheelSpeed);

10. RightFrontWheel. setSpeed (-wheelspeed);

11. RightBackWheel. setSpeed (-wheelSpeed);

12. \}

13. void moveSidewaysRight() \{

14. LeftFrontWheel. setSpeed (wheelspeed);

15. LeftBackWheel.setSpeed (-wheelSpeed);

16. RightFrontWheel.setSpeed(-wheelSpeed);

17. RightBackWheel. setSpeed(wheelspeed);

18. \}

19. void moveSidewaysLeft () \{

20. LeftFrontWheel.setSpeed (-wheelspeed);

21. LeftBackWheel. setSpeed (wheelspeed);

22. RightFrontWheel. setSpeed(wheelspeed);

23. RightBackWheel.setSpeed(-wheelSpeed);

24. \}

25. void rotateleft () \{

26. LeftFrontWheel . setSpeed (-wheelspeed);

27. LeftBackWheel. setSpeed (-wheelspeed);

28. RightFrontWheel. setSpeed(wheelSpeed);

29. RightBackWheel.setSpeed (wheelspeed);

30. \}

31. void rotateRight() \{

32. LeftFrontWheel.setSpeed(wheelspeed);

33. LeftBackWheel. setSpeed (wheelspeed);

34. RightFrontWheel. setSpeed(-wheelspeed);

35. RightBackWheel. setSpeed(-wheelSpeed);

36. \}

37. void moveRightForward() \{

38. LeftFrontWheel.setSpeed(wheelspeed);

39. LeftBackWheel. setSpeed $(\theta)$;

40. RightFrontWheel. setSpeed $(\theta)$;

41. RightBackWheel. setSpeed(wheelspeed);

42. \}

43. void moveRightBackward() \{

44. LeftFrontWheel. setSpeed $(\theta)$;

45. LeftBackWheel. setSpeed (-wheelSpeed);

46. RightFrontWheel. setSpeed(-wheelspeed);

47. RightBackWheel. setSpeed $(\theta)$;

48. \}

49. void moveleftForward() \{

50. LeftFrontWheel. setSpeed $(0)$;

51. LeftBackWheel. setSpeed (wheelspeed);

52. RightFrontWheel. setSpeed (wheelspeed);

53. RightBackWheel. setSpeed (0);

54. \}

55. void moveleftBackward() \{

56. LeftFrontWheel. setSpeed (-wheelspeed);

57. LeftBackWheel. setSpeed $(\theta)$;

58. RightFrontwheel. setSpeed $(\theta)$;

59. RightBackWheel. setSpeed (-wheelspeed);

60. $\}$

61. void stopMoving() \{

62. LeftFrontWheel. setSpeed $(\theta)$;

63. LeftBackWheel. setSpeed $(\theta)$;

64. RightFrontWheel. setSpeed $(\theta)$;

65. RightBackWheel. setSpeed $(0)$;

66. $\}$

Algoritma 1. Potongan Kode Program Kendali Roda Mecanum

\section{Perbandingan harga APD dengan Robot}

Untuk pengukuran efektifitas penggunaan robot, dilakukan perbandingan antara harga dan jumlah APD yang dibutuhkan dengan penggunaan robot ini. Acuan yang digunakan adalah standar dari RSPI Sulianti Saroso, untuk satu pasien dibutuhkan 20 set APD dengan Tingkat Perlindungan III lengkap dalam 24 jam dan satu kali pakai. Satu set pakaian tersebut adalah masker bedah, Respirator N95, Pelindung Mata, Pelindung wajah, Sarung Tangan Pemeriksaan, Sarung Tangan Bedah, Gaun sekali pakai, Coverall Medis, Heavy Duty Apron, Sepatu boot anti air, dan Penutup sepatu. Harga diambil berdasarkan tiap bagian APD di pasar daring. Untuk komponen harga pada robot, diperlukan konversi dalam bentuk dolar dengan satuan harga pada hari ini (16 Juni 2020) dengan mempertimbangkan nilai pajak impor yang mengikuti berdasarkan nilai tukar Bank Indonesia per \$1 terhadap nilai rupiah. Harga komponen robot didapatkan dari pasar daring juga. TABEL VIII menunjukkan total harga yang diperlukan untuk 20 set APD dalam satu hari untuk tiap pasien dan TABEL IX menunjukkan harga yang diperlukan untuk membuat satu buah robot. Terlihat perbedaan harga yang mencolok antara harga APD dengan robot yang dibuat. Namun, untuk penggunaan jangka panjang, penggunaan robot bernilai sangat ekonomis. Untuk mendapatkan harga yang sama dengan robot, dilakukan pembagian antara harga robot dengan biaya APD setiap hari, dan hasilnya adalah hanya dibutuhkan 3,65 hari atau dibulatkan menjadi 4 hari. Jadi, dengan penggunaan APD selama 4 hari sesuai standar RS Sulianti Saroso, kira-kira setara dengan biaya sebuah robot.

TABEL VIII. HARGA TOTAL 20 SET APD UNTUK TIAP

\begin{tabular}{|c|l|r|r|}
\hline No & \multicolumn{1}{|c|}{$\begin{array}{c}\text { Bagian } \\
\text { APD }\end{array}$} & \multicolumn{1}{c|}{$\begin{array}{c}\text { Harga } \\
\text { Satuan }\end{array}$} & $\begin{array}{c}\text { Harga } \\
\text { Total (Rp) }\end{array}$ \\
\hline 1 & Masker bedah & 6.000 & 120.000 \\
\hline 2 & Respirator N95 3M & 50.000 & 1.000 .000 \\
\hline 3 & Pelindung Mata & 75.000 & 1.500 .000 \\
\hline 4 & Pelindung Wajah & 10.000 & 200.000 \\
\hline 5 & $\begin{array}{l}\text { Sarung tangan } \\
\text { pemeriksaan Sensi }\end{array}$ & 1.250 & 25.000 \\
\hline 6 & $\begin{array}{l}\text { Sarung tangan } \\
\text { bedah }\end{array}$ & 7.000 & 140.000 \\
\hline 7 & $\begin{array}{l}\text { Gaun sekali pakai } \\
\text { Gown }\end{array}$ & 100.000 & 2.000 .000 \\
\hline 8 & $\begin{array}{l}\text { Coverall medis } \\
\text { Boho }\end{array}$ & 255.000 & 5.100 .000 \\
\hline 9 & $\begin{array}{l}\text { Heavy Duty Apron } \\
\text { Waterproof }\end{array}$ & 160.000 & 3.200 .000 \\
\hline 10 & $\begin{array}{l}\text { Sepatu Boot anti air } \\
\text { AP Ultraflex }\end{array}$ & 125.000 & 2.500 .000 \\
\hline 11 & $\begin{array}{l}\text { Penutup Sepatu } \\
\text { Safo }\end{array}$ & 100.000 & 2.000 .000 \\
\hline & Jumlah & 889.250 & 17.785 .000 \\
\hline
\end{tabular}


TABEL IX. HARGA TIAP KOMPONEN ROBOT

\begin{tabular}{|c|c|c|c|}
\hline No & Bagian Robot & Jumlah & $\begin{array}{c}\text { Total } \\
\text { Harga (Rp) }\end{array}$ \\
\hline 1 & $\begin{array}{c}\text { Solid Sheet } \\
\text { Polycarbonate } \\
\text { ukuran } 8 \mathrm{~mm} \mathrm{x} \\
122 \mathrm{~cm} \mathrm{x} 224 \mathrm{~cm}\end{array}$ & 2 lembar & 5.450 .000 \\
\hline 2 & $\begin{array}{c}\text { Sambungan H } \\
\text { Solid Sheet } \\
\text { Polycarbonate }\end{array}$ & 2 buah & 250.000 \\
\hline 3 & $\begin{array}{c}\text { Seng Galvanis } \\
\text { Talang Meteran } \\
0.5 \mathrm{~mm} \times 120 \mathrm{~cm} \mathrm{x} \\
250 \mathrm{~cm}\end{array}$ & 2 lembar & 750.000 \\
\hline 4 & $\begin{array}{l}\text { Solid Gerendel } \\
\text { pintu ukuran 3" }\end{array}$ & 8 buah & 240.000 \\
\hline 5 & $\begin{array}{c}\text { Duct tape Scotch } \\
\text { 3939 3M HEAVY } \\
\text { DUTY }\end{array}$ & 2 buah & 450.000 \\
\hline 6 & $\begin{array}{l}\text { Tabung Oksigen } \\
1 \mathrm{~m} 3 \text { sekali pakai } \\
\text { untuk maksimal } 4 \\
\text { jam termasuk } \\
\text { regulator }\end{array}$ & 1 tabung & 850.000 \\
\hline 7 & $\begin{array}{l}\text { Masker Oksigen } \\
\text { Maxiflow tiap } \\
\text { personel medis }\end{array}$ & 2 buah & 50.000 \\
\hline 8 & $\begin{array}{c}\text { Walkie talkie } \\
\text { Walkie Talkie } \\
\text { Uniden GMR3799 } \\
\text { untuk komunikasi } \\
\text { dengan pasien dan } \\
\text { ruang kontrol }\end{array}$ & 2 set & 1.500 .000 \\
\hline 9 & $\begin{array}{c}\text { Seal sarung } \\
\text { tangan karet } \\
\text { Pneumatic Seal } \\
\text { EU } \\
25 \mathrm{~mm} * 35 \mathrm{~mm} * 11 . \\
\text { 2mm Standar } \\
\text { PAKER USA }\end{array}$ & 3 set & 150.000 \\
\hline 10 & $\begin{array}{c}\text { Sarung tangan } \\
\text { karet ukuran 30in } \\
\text { x 9in }\end{array}$ & 3 set & 1.200 .000 \\
\hline 11 & $\begin{array}{c}\text { Silicon Seal } \\
\text { TOHO Heavy } \\
\text { Duty } \\
\end{array}$ & 5 buah & 625.000 \\
\hline 12 & $\begin{array}{l}\text { Kursi lipat tentara } \\
\text { digunakan untuk } \\
\text { duduk didalam }\end{array}$ & 1 buah & 100.000 \\
\hline 13 & $\begin{array}{c}\text { Blockboard } \\
\text { ukuran } 18 \mathrm{~mm} \text { x } \\
122 \mathrm{~cm} \mathrm{x} 224 \mathrm{~cm}\end{array}$ & 3 lembar & 750.000 \\
\hline 14 & $\begin{array}{l}\text { Steel Mecanum } \\
\text { Wheel ukuran } \\
254 \mathrm{~mm} \times 95 \mathrm{~mm} \\
\text { (4 roda) tanpa } \\
\text { pajak }\end{array}$ & 1 set & 8.360 .065 \\
\hline 15 & $\begin{array}{c}\text { Battery Pack } \\
\text { Lithium Life PO4 } \\
\text { 12V 40AH } \\
\text { berdimensi } \\
\text { 328mm x } 195 \mathrm{~mm} \\
\text { x } 22 \mathrm{~mm}\end{array}$ & 8 pack & 21.200 .000 \\
\hline 16 & $\begin{array}{l}\text { Motor listrik DC } \\
\text { atau Stepper (torsi } \\
\text { minimum } 12 \mathrm{Nm} \text { ) } \\
\text { dengan tipe } \\
\text { NEMA42 Stepper } \\
\text { Motor } 21 \mathrm{Nm} \text { tidak } \\
\text { termasuk pajak }\end{array}$ & 4 motor & 6.000 .000 \\
\hline 17 & Roda gigi dan & 4 set & 7.000 .000 \\
\hline
\end{tabular}

\begin{tabular}{|c|c|c|c|}
\hline & $\begin{array}{c}\text { rantai untuk } \\
\text { penggerak roda } \\
\text { ukuran } 1: 2\end{array}$ & & \\
\hline 18 & $\begin{array}{c}\text { Perangkat } \\
\text { pengendali robot } \\
\text { termasuk } \\
\text { kontroler, motor } \\
\text { driver, dan battery } \\
\text { management } \\
\text { system }\end{array}$ & 1 set & 2.500 .000 \\
\hline 19 & $\begin{array}{c}\text { Wall hook - } \\
\text { Command - 17004 } \\
\text { Jumbo Hook } \\
\text { untuk beban 3kg }\end{array}$ & 10 buah & \\
\hline 20 & $\begin{array}{l}\text { Biaya } \\
\text { pemotongan, } \\
\text { pembuatan, dan } \\
\text { perakitan dengan } \\
\text { lima orang pekerja }\end{array}$ & & \\
\hline \multicolumn{2}{|c|}{ Total } & \\
\hline
\end{tabular}

\section{KESIMPULAN DAN SARAN}

Dari hasil desain yang telah dibuat, didapatkan bahwa tabung tersebut memiliki kemampuan untuk mengamankan tenaga medis hingga 8 jam. Tenaga medis juga dapat dengan nyaman berada didalam tabung robot tersebut dengan tingkat perlindungan tinggi dan mudah untuk keluar masuk tabung jika diperlukan. Selain itu, proses sterilisasi juga mudah dan aman. Dengan adanya pelindung ganda dibagian dalam, tenaga medis tidak perlu khawatir sama sekali akan terpapar sinar ultraviolet untuk sterilisasi maupun ketika harus disemprot dengan disinfektan. Tabung pelindung tersebut juga memiliki kekuatan 30 kali lipat lebih kuat daripada kaca dan tidak mudah pecah ketika terbentur. Dari bagian dalam, dengan adanya tiga bagian tangan untuk posisi diatas kepalam sejajar bahu dan berlutut, petugas medis dapat dengan mudah melakukan pekerjaannya untuk mengambil barang-barang yang ada di kamar isolasi pasien atau hanya sekedar melakukan pengecekan perangkat pada pasien yang berstatus gawat. Untuk proses komunikasi dengan pasien, dapat digunakan tambahan alat komunikasi pribadi yang dapat dihubungkan dengan WiFi yang ada di ruangan isolasi tersebut. Tabung ini akan memberikan semangat dan dukungan lebih terhadap pasien COVID-19 yang menjalani isolasi maupun perawatan intensif. Untuk mempercepat pembuatan tabung robot, bahan-bahan yang dibutuhkan sudah tersedia seluruhnya didalam negeri, kecuali LoRa, modul GPS, roda mecanum, dan mesin penggeraknya.

Motor penggerak menggunakan motor stepper dengan torsi $21 \mathrm{Nm}$ dengan konsumsi arus sebesar 5A. Agar dapat digunakan dengan aman, digunakan motor tersebut karena hanya membutuhkan sekitar 50\% dari kemampuan motor untuk menggerakkan robot dengan kebutuhan torsi sebesar $11,313 \mathrm{Nm}$ atau dibulatkan menjadi $12 \mathrm{Nm}$. 
Robot dapat bergerak maksimal selama 4 jam terusmenerus dengan baterei yang digunakan sebesar 80Ah. Dapat dikatakan, tabung robot memiliki nilai TKDN yang tinggi dan dapat diproduksi massal dengan cepat, namun untuk penggerak tabung, yaitu motor stepper dan roda mecanum memiliki nilai TKDN yang kecil karena harus impor.

\section{REFERENSI}

[1] Al Wardi, Yousuf M., Sasirajan Jeevarathinam, and Saleh H. Al Sabei. "Eastern bodies in western cockpits: An anthropometric study in the Oman military aviation." Cogent Engineering 3, no. 1 (2016): 1269384.

[2] Baxter, M., dan D.W. Ray. "Circadian rhythms in innate immunity and stress responses." Immunology, 2019

[3] Snowden, Austyn, Jenny Young, and Jan Savinc. "Meeting psychosocial needs to improve health: a prospective cohort study." BMC Cancer 20, no. 1 (2020): 1-10.

[4] Chapa, Deborah W. "Improvement of Psychosocial Outcomes in Patients with Critical Care Illness Positively Impacts Outcomes for Patients and Caregivers." Critical Care Nursing Clinics of North America 31, no. 4 (December 2019): ix-X.

[5] COVID-19, Gugus Tugas Penanganan. Rekomendasi Standar Penggunaan APD untuk Penanganan COVID-19 di Indonesia. 22 April 2020. https://perdhaki.org/wpcontent/uploads/2020/04/Rekomendasi-StandarPenggunaan-APD.pdf.

[6] Farooqui, Rizwan M., and R. B. Shahu. "Analysis of anthropometric dimensions for sitting posture and chair design: a review." Int J Innov Eng Technol (IJIET) 6 (2016).

[7] Indonesia, Antropometri. Data Antropometri. t.thn. https://antropometriindonesia.org/index.php/detail/artikel/4 $/ 10 /$ data antropometri.

[8] Indozone.id. Cerita Sang Anak, Detik-detik Guru Besar UI Bambang Sutrisna Meninggal dalam Kesendirian. 24 Maret 2020. https://www.indozone.id/news/pQsZRP/cerita-sanganak-detik-dekit-guru-besar-ui-bambang-sutrisnameninggal-dalam-kesendirian/read-all.

[9] Kesehatan, Direktorat Jendral Kefarmasian dan Alat. Standar APD dalam Manajemen Penanganan Covid 19. 22 April 2020. https://perdhaki.org/wpcontent/uploads/2020/04/Standar-APD-dalam-ManajemenPenanganan-Covid19.pdf

[10] Kuk, Jennifer L., Chris I. Ardern, Timothy S. Church, James R. Hebert, Xuemei Sui, dan Steven N. Blair. "Ideal Weight and Weight Satisfaction: Association With Health Practices." American Journal of Epidemiology 170, no. 4 (2009): 456-463.

[11] M., Kohut, Alley J., Jepsen M., Elkhatib S., Smeins L., dan Ackermann M. "Human respiratory mucosal immunity is altered by stress." Brain, Behavior, and Immunity 66, Suplement (2017): e42.

[12] Mersin, S, M Demiralp, dan E Öksüz. "Addressing the psychosocial needs of patients: Challenges for nursing students." Perspect Psychiatr Care 55 (2019): 269- 276

[13] Mitchell, M., dan D Wilson. "Family and cultural care of the critically ill patient." Critical Care Nursing, 2019: 171.

[14] Prima, Erwin, and Moh Khory Alfarizi. Tempo.co. April 16, 2020. https://tekno.tempo.co/read/1332046/raisa-robotpelayan-pasien-covid-19-karya-its-dan-rs-unair.

[15] Rebecca, Dumbell, Matveeva Olga, dan Oster Henrik. "Circadian Clocks, Stress, and Immunity." Frontiers in Endocrinology 7 (2016): 37.

[16] Scalzo, Flavio Lo, Philip Pullella, and Alexandra Hudson. Reuters.com. April 1, 2020. https://www.reuters.com/article/us-health-coronavirus- italy-robots/tommy-the-robot-nurse-helps-keep-italydoctors-safe-from-coronavirus-idUSKBN21J67Y.

[17] Şenol, Mehmet Burak. "Anthropometric evaluation of cockpit designs." International journal of occupational safety and ergonomics 22, no. 2 (2016): 246-256.

[18] Shorofi, SA, Y Jannati, HR Moghaddam, dan J YazdaniCharati. "Psychosocial needs of families of intensive care patients: Perceptions of nurses and families." Niger Medical Journal 57, no. 1 (2016): 10-18.

[19] Sonawane, Nishant. "An Experimental Method to Calculate Coefficient of Friction in Mecanum Wheel Rollers and Cost Analysis Using DFMA Techniques." (2015).

[20] Von-Maszewski, Marian, dan Virginia Schneider. "363 TRAINEES IN THE ICU: ACADEMIC AND PSYCHOSOCIAL NEEDS." Critical Care Medicine 46, no. 1 (2018): 164.

[21] Whittaker, Anna C., dan Stephen Gallagher. "Caregiving alters immunity and stress hormones: a review of recent research ." Current Opinion in Behavioral Sciences 28 (2019): 93-97. 